\title{
The plasticity of fungal interactions
}

\author{
Marta Wrzosek $^{1}$ - Malgorzata Ruszkiewicz-Michalska ${ }^{2}$ - Katarzyna Sikora ${ }^{3}$. \\ Marta Damszel $^{4} \cdot$ Zbigniew Sierota $^{5}$
}

Received: 10 June 2016 /Revised: 5 December 2016 / Accepted: 7 December 2016 / Published online: 26 December 2016

(C) The Author(s) 2016. This article is published with open access at Springerlink.com

\begin{abstract}
Their hyphal structure, the common events of hybridization and horizontal gene transfer, as well as intimate associations with prokaryotes (including endobiotic bacteria) and cooperation with eukaryotes have made fungi very flexible at the genetic, physiological, and ecological levels. It is manifested with the fungal ability to perfectly exploit existing nutrient sources and plastically fit into a changing environment. Although the links between fungi and other ecosystem components are rarely clearly visible and unambiguous, fungi can be ecosystem buffers playing a homeostatic role throughout global ecosystems, reacting to changes in various ways, not only by modifications of gene expression but also by nuclear status and "extended phenotype". The goal of this review is to underline some ecological interactions involving
\end{abstract}

Section Editor: Marc Stadler

Zbigniew Sierota

zbigniew.sierota@uwm.edu.pl

1 Department of Molecular Phylogenetics and Evolution, Faculty of Biology, Biological and Chemical Research Centre, University of Warsaw, Żwirki i Wigury 101, 02-089 Warsaw, Poland

2 Department of Algology and Mycology, Faculty of Biology and Environmental Protection, University of Łódź, Banacha 12/16, 90-237 Łódź, Poland

3 Department of Forest Protection, Forest Research Institute, Sękocin Stary, Braci Leśnej 3, 05-090 Raszyn, Poland

4 Department of Entomology, Phytopathology and Molecular Diagnostics, Faculty of Environmental Management and Agriculture, University of Warmia and Mazury in Olsztyn, Prawocheńskiego 17, 10-721 Olsztyn, Poland

5 Department of Forestry and Forest Ecology, Faculty of Environmental Management and Agriculture, University of Warmia and Mazury in Olsztyn, Plac Łódzki 2, 10-727 Olsztyn, Poland fungi and other organisms and to indicate high fungal plasticity in terms of ontogenetic perspective.

Keywords Fungal ecology $\cdot$ Mutualism $\cdot$ Parasitic fungi · Decomposition $\cdot$ Interspecies interaction

\section{Introduction}

According to the biological species concept, a 'species' is defined as one or more groups of interbreeding natural populations that are reproductively isolated from other such groups that occupy a specific ecological niche (Mayr 1942). In such a context, genetic information can be transmitted only within a species. For some reasons, this concept does not hold for fungi, which has been discussed by, e.g., Taylor et al. (2000) and Cai et al. (2011).

Although ecology as a biological discipline was formed on the basis of plant and animal studies, it is the uniqueness of fungal biology that can help to understand the complex ecological relationships. Some fungal characters are widely known and understood, while some others are still under discussion and yet to become widely studied. The hypha, with its unusual type of cell organization unknown among other living organisms, belongs to the former group, while among the latter, in fungi it is difficult to define an individual, which is a highly important character when comparing fungi and macroeukaryotes. Also, fungi are capable of performing anastomosis, the fusion of encountering vegetative hyphae, resulting in heterokaryosis, i.e., the advantage of having two genomes instead of a single one (Chagnon 2014; Strom and Bushley 2016). Furthermore, fungal reproduction is quite unusual. In contrast to plants and animals, the fungal nuclei can exchange DNA by parasexual processes resulting in increased variation in the genotype while avoiding the costs of sexual 
reproduction, as observed specifically in basidiomycetes. Parasexuality, primarily discovered for fungi (Pontecorvo 1956), is sharing with many microeukaryotes (Speijera et al. 2015; Sterkers et al. 2014; Weedall and Hall 2015; Tekle et al. 2014), but not with macroeukaryotes, so the results of fungal heterokaryosis have a greater impact on the environment. Parasexual processes are observed throughout the fungal kingdom. It has been confirmed to occur in different strains of a single species, e.g., Metarhizium strains inside individual insect hosts(Figueirêdo and Silva 2001). Heterokaryotic fungi produce spores which can be multikaryotic, i.e., those of Glomales and Entomophthorales (Chagnon 2014; Burnett 2003). In addition, the primary spores of some Entomophthorales give rise to secondary spores with diverse characteristics (Wieloch et al. 2004), while several different strains can be obtained from a single Mucor mucedo asexually produced sporangium (Burnett 2003). Thus, using methods and terms derived from animal ecology can be a questionable way of characterizing diversity of fungal communities and population sizes. The frequency of asexual reproduction and parasexual episodes often makes it difficult to define the boundaries not only for individuals but also for species. Resolving this with molecular tools is based on the detection of discontinuities rather than being specified by a fixed percentage of sequence similarity (Guo 2010).

One of the mechanisms that circumvent reproductive isolation is interspecific hybridization. Generally, hybridization can be treated as a sudden, dramatic increase in heterozygosity. In some cases, hybridization of pathogenic species has increased virulence, extended host ranges, and facilitated the occupation of new niches (Kroon et al. 2012). Hybridization is not always beneficial, though, as a newly established hybrid species may be affected by a strong population bottleneck, especially when the population size is small (Stukenbrock et al. 2011). Hybrids with increased virulence and extended host ranges can emerge rapidly as a consequence of human activity. Co-evolution of pathogens and plants has forced the latter to develop specific defense systems. The introduction of a hybrid pathogen to an environment interferes with preexisting environmental balances, which may result in outbreak events (Brasier 2003, 2008).

The other essential issue is horizontal gene transfer (HGT). Horizontal transfer of functional genes and transposable elements between genomes of parasitic fungi and their hosts has already been documented for plant-associated species (Wijayawardena et al. 2013; Qiu et al. 2016), as well as for fungi and bacteria (Richards et al. 2011; Lacroix and Citovsky 2016). HGT is currently known to be more common than earlier assumed, as well as highly important in fungal evolution (Richards et al. 2011; Fitzpatrick 2012; Qiu et al. 2016). Many episodes of acceleration appear to have followed ecological shifts and the occupation of new environments (Lumbsch et al. 2008). Lutzoni and Pagel (1997) have demonstrated the case of accelerated evolution as a consequence of transition to mutualism.

Finally, an essential difference between fungi and other eukaryotes is the flexibility in shifting ecological status in the face of modifications of abiotic/biotic factors. At least a part of fungal plasticity can be explained by the acquisition of bacterial or eukaryotic genes, gene clusters or entire chromosomes, including supernumerary ones (Fitzpatrick 2012). This phenomenon is the best studied in the case of genes associated with fungal pathogenesis and virulence (Richards et al. 2011; Lacroix and Citovsky 2016; Qiu et al. 2016).

In this review, several examples of fungal plasticity in relation to other organisms are highlighted. At a larger, ecological scale they could be considered as manifestations of the buffering effect of fungi and their amazing ability to survive under varying conditions and to make maximum use of available niches. We specifically focus on the following issue: examples highlighting the role of fungi in the environment after unexpected changes of biotic and abiotic factors and fungi modifying their ecological status during ontogeny, as well as reciprocal relationships of fungi and prokaryotes/eukaryotes, including the adaptability driven by HGT.

\section{Fungal associations with bacteria}

Conventionally, lichens are well known as an example of dual mutualistic symbiosis involving fungal and photosynthetic partners. The intimate trait of a majority of lichen symbioses is the production of secondary metabolites with numerous biological roles, such as photoprotection, metal homeostasis, and pollution tolerance of lichen thalli (Molnár and Farkas 2010; Zedda and Rambold 2015). They also have allelochemical, antiviral, antibacterial, antiherbivoral, anti-oxidant, and antitumor properties. Although the nature of the relationships in lichens is still the subject of debate, it is widely accepted that it ranges from mutualism to controlled parasitism and changes dynamically over time (e.g., Ahmadjian and Jacobs 1981; Nash 1996; Richardson 1999). The definition of a lichen is further complicated by the presence of diverse, thallus-associated eukaryotic and prokaryotic entities (Zedda and Rambold 2015), including fungi (parasites, saprotrophs, and parasymbionts; Hawksworth 1982, 2015; Lawrey and Diederich 2003; Selbmann et al. 2013), non-symbiotic algae (diatoms; Lakatos et al. 2004), terrestrial and aquatic invertebrates (arthropods, nematodes, Alveolata, Metazoa, Rhizaria; Bates et al. 2012), protists (Šatkauskienè 2012), as well as bacterial communities (Bates et al. 2011; Aschenbrenner et al. 2016). Providing favorable conditions for other organisms, the lichen thallus appears to constitute an ecological niche (Hawksworth 1982) or even a miniature, intricate ecosystem (Aschenbrenner et al. 2016), as already postulated in the 1970s (Farrar 1976). Its complexity is further increased by 
the high variety of genotypes of eukaryotes and prokaryotes coexisting within a single species or even a single thallus. Although this phenomenon is known for myco- and photobionts, the level of genetic diversity is still largely unexplored, except for cyanobacteria (Zedda and Rambold 2015, and literature cited therein).

Most probably, lichen microbiomes are vertically transmitted together with vegetative propagules. It has been suggested that they receive a 'bacterial starter community' from parental symbiosis that partly differs in composition from the parental community present in parental symbiosis (Aschenbrenner et al. 2016). The role of those bacteria in nutrient supply, the biosynthesis of vitamins and hormones, and detoxification has been revealed in studies of Lobaria pulmonaria-associates. The lichen-associated bacteria also assist in the protection against stress of biotic (including pathogens) and abiotic (desiccation) origin (Cernava et al. 2015). Being a non-hostspecific reservoir of bacteria, lichen symbiosis has been perceived as a source of both pathogenic and beneficial strains, including plant growth-promoting bacteria (Cernava et al. 2015; Aschenbrenner et al. 2016; Vilhelmsson et al. 2016). The question of wherever the lichen microbiomes may constitute a gene pool available for horizontal genetic exchange is still to be addressed.

Environmental plasticity of lichen-forming species is primarily reflected by the elementary ability to switch the fungal nutrition mode from saprotrophic to symbiotic. This was first confirmed by Wedin et al. (2004) for the Stictis-Conotrema complex from boreal aspen stands; the authors regarded such optional lichenization as an overlooked strategy in fungi which broadens the species ecological amplitude and facilitates the exploitation of different niches during ecosystem succession.

Lichen microbiome plasticity and its buffering effect on macro-ecosystems is based on niche-providing phenomena and the diversity and role of secondary metabolites, as well as HGT. Molecular studies suggest that the ancient episodes of gene transfer between fungi (donor) and algae (recipient) took place before the first events of lichen symbiosis (Beck et al. 2015). Additionally, it is hypothesized that such a gene exchange could have played a pre-dispositional role in the symbiosis origin (Beck et al. 2015). The great role of HGT is also emphasized in the evolution of 'classical' partners of the lichen symbiosis: cyanobacteria, green algae and fungi (Tunjič and Korač 2013). Separately evolving symbionts, adapting to environment and partners, may be advantageous for lichen symbiosis.

Bacteria-induced change in the ecological status of fungi was reported in the case of, e.g., the Oryza-RhizopusBurkholderia tripartite system by Partida-Martinez and Hertweck (2005). They demonstrated the pathogenic impact of various strains of common Rhizopus saprotrophs on rice seedlings caused by Burkholderia bacteria living inside the fungal hyphae. The recently disputed role of bacteria in the formation of Tuber ascocarps (Le Tacon et al. 2016) relies on bacterial help in the shifting of the nutrition mode of developing ascocarps from mycorrhizal to saprotrophic. The presence of prokaryotes in hyphae could be a common and powerful source of physiological variation.

\section{Endophytes, invertebrates and winter desiccation}

The unexpected changes in circadian air temperatures when the roots are still dormant might be the primary cause of the strong winter desiccation injury of whole Scots pine Pinus sylvestris branches. Tranquillini (1982) and Sierota et al. (1998) described how low $\left(-1{ }^{\circ} \mathrm{C}\right.$ and lower) or freezing temperatures can reduce or completely interrupt water transport from the roots, as well as injure needles, new shoots, and buds. The low temperatures interrupted the mechanisms of frost resistance, which was followed by damage to the cell membrane structure of the needles, which released sugars to protect thylakoids, as described by Santarius (1973). What is the role of fungi in this process?

This cold-based phenomenon appears to be simple, but it was complicated by the common presence of the endophytes Cenangium ferruginosum and Scoleconectria cucurbitula observed on a mass scale (Sierota et al. 1998). Both species had been isolated earlier by Kowalski $(1982,1993)$ and Kowalski and Zych (2002) from needles of Pinus nigra in industrial regions or from necrotic plant tissue of shoots with needles damaged by the gall midge Thecodiplosis brachyntera (Kowalski 1998). Increased nutrient levels (i.e., an excess supply of nutrients) had increased the "attractiveness" of needles for endophytes which then overcame the plants' defense.

Symbiotic endophytes effectively switched to biotrophic, not parasitic, behavior. In the Scots pine case, frost was the destructive agent while fungi provided a buffering role. Low night temperatures and high day temperatures caused Pinus sylvestris destruction of tissues, and the available carbohydrates were utilized by endophytes. The presence of Pinus sylvestris European pine needle midge Contarinia (= Cecidomyia) baerii Prell. decreased with the increasing occurrence of non-systemic endophytic fungi (Sierota et al. 1998), which is in accordance with the findings of Clay (1987) regarding systemic, grass-associated endophytes and herbivores.

Minor changes in air temperature may result sometimes also in sudden and unpredictable collapse of invertebrate populations (Manion 1981). This may greatly influence animal population (size and density of mature insects or feeding larvae) because of the simultaneous increase of infestations by fungi, e.g., Beauveria bassiana (Jaworski and Hilszczañski 2013; Grodzki and Kosibowicz 2015). The progress of fungal infestation in the disease or decay process is determined by 
many factors, including susceptibility of a host, favorability of environmental conditions, and the period of time that has elapsed (White et al. 1996; Manion 1981; Hatcher and Paul 2001; Elliott et al. 2002).

Transcriptome studies in two time points should be performed to understand the dynamics of interaction between individuals, as proposed by Małagocka et al. (2015) for interactions between fungi and insects. Such an approach is desirable to understand the mechanisms of changes. Fungal endophytes are often commensals, but can also be mutualists that provide anti-insect resistance and are even considered an element of "acquired plant defenses" in cases of systemic endophytes (Cheplick et al. 1989; Clay 1991). Faeth and Fagan (2002) demonstrated the potentially negative effect of endophytes on hosts in nitrogen-rich environments with low risks of insect herbivory. Endophytes can produce extracellular oxidases and cause dieback of plant tissue (Butin and Kowalski 1992). Their presence has also been confirmed in dead tissue, the endophytes having passed from weak parasitism to a saprobic lifestyle. This is not the first example of a fungus switching its lifestyle. Phialocephala spp. are considered root endophytes and mutualists, but they are also observed on dead wood as saprotrophs (Pirttilä and Wäli 2009). Lee Sun et al. (2014) described the impact of Cenangium as endophyte and saprotroph on pines. Fungi with such changing lifestyles can be considered as "ecological regulators" or "ecological buffers".

Individually, both insects and fungi can have harsh impacts on host plants, but together their deleterious effects are reduced (Hatcher 1995). Still, this insurance is a trade-off between benefits and losses.

\section{Ambivalent role of fungi infecting arthropods}

Many fungi are pathogens of pests (e.g., Brixey 1997; Fătu et al. 2015) but only a few have the potential to kill a wide spectrum of hosts. Entomopathogens with broad host ranges (generalists) exhibit relatively low virulence in comparison with specialists (Goettel 1995). The most specific fungal pathogens are within the Laboulbeniales order; some of these species are restricted to certain parts of the host' carapace (Kaur and Mukerji 2006). This unusual specificity is surprising, but it may be explained by precise and unique modes of spore dispersal. A recent study by Konrad et al. (2015) demonstrated a potential advantage of infection by a specialized pathogen: resistance to a second, typically generalist fungus. Konrad et al. (2015) tested the effects of Laboulbenia formicarum infection on the invasive garden ant Lasius neglectus. The fitness consequences of this pathogen on its hosts were context-dependent, and even massive Laboulbenia infestations were beneficial during concurrent infections with another, lethal pathogen, namely Metarhizium brunneum. The fitness of ants parasitized by Laboulbenia decreased in starvation, but higher levels of Laboulbenia infection increased host survival under M. brunneum exposure. The benefits of Laboulbenia are probably due to stimulation of the immune system and an intensification of grooming behaviors. Konrad et al. (2015) also demonstrated that starvation of an insect host is a factor that can convert fungal commensals to weak pathogens.

\section{The multifaceted Trichoderma}

Trichoderma fungi (Hypocreales) are microorganisms regarded as antagonistic to many plant pathogens and used to induce resistance against them, and to reduce the severity of plant diseases in biological crop protection (Butt and Copping 2000; Chetan et al. 2014). Trichoderma asperellum, T. viride, T. harzianum, and T. atroviride are the main species used in biological preparations as effective bio-pesticides against pathogenic Fusarium, Pythium, Phytophthora, Alternaria, Sclerotinia, Botrytis, and others (Regliński et al. 2012; Minchin et al. 2012). Although their effectiveness has been confirmed (Sierota 1976; Howell 2006; Tucci et al. 2011; Patil et al. 2012), some authors (e.g., Kredics et al. 2003) dispute the unambiguous antagonistic properties of Trichoderma against pathogens. The role of the environmental context, such as the soil C:N ratio, the abundance of phosphorus and carbon, moisture level, $\mathrm{pH}$, temperature, UV radiation, and the presence of other microorganisms is highlighted.

The mechanisms of competition with other organisms that are based on the production of harzianic acid, glovirin, alamenthicin, and other siderophores, as well as antibiotics and enzymes used by some Trichoderma species, rely on the colonization of free niches during the infection process. A plant immune system is induced (via both acquired and induced systemic resistance), as reported for plants experimentally conditioned with Trichoderma (Sobolewski et al. 2013). Metabolic activity of hypocrealean fungi is also referred to as an important component in the co-evolutionary transition between host and pathogen, during which Trichoderma assumes the role of 'armed tenant' (Bettiol and Morandi 2008).

The expansive colonization of physio-chemically diverse environments and resistance to toxic pesticides (including strategies to increase mycelium division and the transfer of the $\mathrm{ABC}$ transporter, even following exposure to sub-lethal doses of plant protection compounds) can evolve in extreme ecological niches of Trichoderma (Benítez et al. 2004; Harman et al. 2004). In addition, some Trichoderma species use mycorrhizal fungi as a gateway to colonize plant tissues, and therefore they are isolated as intercellular colonizers of plant roots. Trichoderma fungi are thus symbionts, but they fulfil this role as opportunists (Harman et al. 2004). The transition of these fungi from mutualism (biotrophy) to 
commensalism appears labile. Recent comparative genomic studies confirm the evolutionary changes in the lifestyle of Trichoderma species. The comparison of their gene pool with other pathogenic ascomycetes indicates that reciprocal transfer of genetic information and protein effectors was very likely. These horizontally transferred genetic elements could push nutrition from saprotrophic towards a more pathogenic mode by stimulating the host cell reactions (Druzhinina et al. 2011).

Trichoderma species can be interpreted as saprotrophs with strong ability of antagonistic interactions. The production of broad-spectrum enzymes and antibiotics conducive to their opportunistic nature facilitates its expansion within an environment.

\section{Pathogenic fungus as a selection factor}

The process of hybridization gives a powerful illustration of the buffering role of fungi. The hybrid poplar rust Melampsora $\times$ columbiana (M. medusae $\times$ M. occidentalis) replaced its progenitors as the dominant poplar pathogen and was a massive threat to poplar plantations in the United States in the 1980s. Compared to the hybrid, the progenitors were less virulent and had distinct host ranges. It is worth noting that poplar hybrid Populus deltoides $\times$ P. trichocarpa which were designedly bred to achieve resistance toward M. occidentalis, were infected with the newly emerged fungal hybrid, $M . \times$ columbiana. Symptoms of the diseases were also found earlier on both parental poplar species, $P$. deltoides and P. trichocarpa (Newcombe et al. 2000). If the poplars were not a cultivated species, the impact of fungal parasites in plant monocultures could be considered a restoration of the natural balance and the damage would have been negligible. In such a case, massive appearance of Melampsora hybrids on poplars could be treated as homeostasis recovery provided by the fungus that is restoring a more complex ecosystem in an area changed profoundly by human activity.

The fungus causing Dutch elm dieback that occurred twice in the past century in Europe is another example of hybridization of pathogenic species. For the first outbreak, the pathogenic ascomycete Ophiostoma ulmi was responsible (Gibbs 1978). In the 1940s, the second outbreak was caused by its more aggressive relative Ophiostoma novo-ulmi, which consists of two subtaxa: O. novo-ulmi subsp. novo-ulmi (Brasier 1979) and O. novo-ulmi subsp. americana (Brasier and Gibbs 1973). Both of these subspecies originated in Asia and were introduced into Europe by humans, most likely with the transport of infected elm logs. In the new territory, the previously isolated pathogens started to rapidly hybridize, and new O. novo-ulmi subsp. novo-ulmi $\times$ americana hybrid emerged. It had a high growth rate and virulence and until the end of 1980 s it comprised about $80 \%$ of the total population of O. novo-ulmi (Brasier and Kirk 2010).
Adapting the species concept to include hybridization is a more general problem also, emphasized in cases of oomycotan fungal analogues (Husson et al. 2015). Recently, Husson et al. (2015) have described the hybridization between two subspecies with different ploidies and the appearance of a new hybrid subspecies. The authors found that the new hybrid DNA was equal to half the sum of the parental DNAs, but one parental genome was tetraploid while the second was diploid. The resulting hybrid is an allotriploid, containing half of the genome of each parental subspecies. Such a situation is far from common in breeding and demands both the use of new terms and a reconsideration of oomycete ecology.

\section{Conclusions}

The innate human need for systematization, categorization and classification of mechanisms governing nature and its components paradoxically biases the knowledge of nature functioning. Fungi, being extremely adaptive eukaryotes, are the prime example enabling one to realize that paradox. Within short time scales, we are restricted to the terms mutualist, pathogen, and commensal when describing fungi. However, it is unclear which environmental factors can shift a fungal pathogen to a mutualist or the converse. Moreover, the pathogen can improve the host fitness in the face of attack from another pathogen as revealed in the studies of Laboulbeniales fungi (Konrad et al. 2015). Also, recognition of Armillaria species as only pathogens is an oversimplification (Baumgartner et al. 2010; Mar ais and Wargo 2000) in the sense of distinguishing between the categorization of a given interaction. The 'pigeonholing' of an organism as, e.g., saprotrophic (including pyrophilic, commensalistic), biotrophic (including mutualistic, neutral, and diverse antagonistic relationships) might be convenient but is faulty in the case of an organism that is able to perform more than one such type of interaction. The ecology of the fungi is a real mine of examples of extended phenotypes (Dawkins 1989). Thus, the role of a fungus primarily referred to as a pathogen is not unambiguous. We emphasize the necessity to avoid simplifications while using terms standard in ecology, e.g., parasite, pathogen, mutualist, etc., as they are not valid for fungi which dynamically change their status. Instead, fungal function in symbiotic continuum should be stressed.

The multifaceted nature of fungi is still not completely clear, and without large environmental analyses and collaboration between researchers, the conclusions from future studies may also be strongly biased by both narrow perspectives and small time scales. At a long time scale, the stabilizing role of fungi in the environment can be observed or deduced. Fungi, as organisms which are exceptionally abundant in ecosystems, are likely to be drivers of natural restoration in disturbed biocoenoses. The flexible nature of fungi, their nuclear 
state, genetic properties, efficiency of new gene acquisition, and hyphal structure underlie theie high adaptive abilities and unique buffering status. They serve as environmental "special services" that may help to establish a new ecological balance after many types of disturbances.

Acknowledgements The authors wish to thank Dr. Scot Nelson (University of Hawaii) for inspiring guidance and helpful comments on an earlier draft of this paper. The authors would also like to thank the anonymous reviewers for their valuable comments and suggestions. This study was partially financed by statutory funds from the Department of Algology and Mycology, University of Łódź and from the Department of Molecular Phylogenetics and Evolution, University of Warsaw, and by own funds of the Department of Forest Protection, Forest Research Institute.

Open Access This article is distributed under the terms of the Creative Commons Attribution 4.0 International License (http:// creativecommons.org/licenses/by/4.0/), which permits unrestricted use, distribution, and reproduction in any medium, provided you give appropriate credit to the original author(s) and the source, provide a link to the Creative Commons license, and indicate if changes were made.

\section{References}

Ahmadjian V, Jacobs JB (1981) Relationship between fungus and alga in the lichen Cladonia cristatella Tuck. Nature 289:169-172. doi: 10.1038/289169a0

Aschenbrenner IA, Cernava T, Berg G, Grube M (2016) Understanding microbial multi-species symbioses. Front Microbiol 7:180. doi:10.3389/fmicb.2016.00180

Bates ST, Cropsey GWG, Caporaso JG, Knight R, Fierer N (2011) Bacterial communities associated with the lichen symbiosis. Appl Environ Microbiol 77(4):1309-1314. doi:10.1128/AEM.02257-10

Bates ST, Berg-Lyons D, Lauber CL, Walters WA, Knight R, Fierera N (2012) A preliminary survey of lichen associated eukaryotes using pyrosequencing. Lichenologist 44(1):137146. doi: $10.1017 / \mathrm{S} 0024282911000648$

Baumgartner K, Coetzee MPA, Hoffmeister D (2010) Secrets of the subterranean pathosystem of Armillaria. Mol Plant Pathol 12(6):515534. doi:10.1111/mpp.2011.12.issue-6

Beck A, Divakar PK, Zhang N, Molina MC, Struwe L (2015) Evidence of ancient horizontal gene transfer between fungi and the terrestrial alga Trebouxia. Org Divers Evol 15(2): 235-248. doi:10.1007/s13127-014-0199-x

Benítez T, Rincón AM, Limón MC, Codón AC (2004) Biocontrol mechanisms of Trichoderma strains. Int Microbiol 7:249-260. doi:10.4172/2169-0111.1000e110

Bettiol W, Morandi MAB (2008) Trichoderma in Brazil: history, research, commercialization and perspectives. In: Duffy B, Maurhoffer M, Keel C, Gessler C, Elad Y, Kiewnick S (eds) Molecular tools for understanding and improving biocontrol. X-th Meet. Work. Gr. Biological control of fungal and bacterial plant pathogens, Interlaken, p 49

Brasier CM (1979) Dual origin of recent elm diseases outbreaks in Europe. Nature 281:78-79. doi:10.1038/281078a0

Brasier CM (2003) Phytophthoras in European forests: Their rising significance. Sudden Oak Death Online Symposium. www.apsnet.org/online/SOD (website of Am Phytopath Soc). doi:10.1094/SOD-2003-CB

Brasier CM (2008) Phytophthora biodiversity: How many Phytophthora species are there? In: Proceedings of the 4th IUFRO workshop on
Phytophthora in forest and natural ecosystems. Goheen E (ed) USDA Forest ser. pp 101-115.

Brasier CM, Gibbs JN (1973) Origin of the Dutch elm diseases epidemic in Britain. Nature 242:607-609

Brasier CM, Kirk SA (2010) Rapid emergence of hybrids between the two subspecies of Ophiostoma novo-ulmi with a high level of pathogenic fitness. Plant Pathol 59:186-199. doi:10.1111/j.1365-3059.2009.02157.x

Brixey J (1997) The potential for biological control to reduce Hylobius abietis damage. Research Information Note Forestry Commission $7 \mathrm{pp}$

Burnett JH (2003) Fungal Population and Species. Oxford University Press, Oxford, pp 162-184

Butin H, Kowalski T (1992) Die natürliche Astreinigung und ihre biologischen Voraussetzungen. V. Die Pilzflora der Kiefer, Fichte und Lärche. Eur J For Pathol 20:44-54. doi:10.1111/j.1439-0329.1990.tb01272.x

Butt TM, Copping LG (2000) Fungal biological control agents. Pest Outl 11:186-191. doi:10.1039/b008009h

Cai L, Giraud T, Zhang N, Begerow D, Cai G, Shivas RG (2011) The evolution of species concepts and species recognition criteria in plant pathogenic fungi. Fungal Divers 50:121133. doi:10.1007/s13225-011-0127-8

Cernava T, Müller H, Aschenbrenner IA, Grube M, Berg G (2015) Analyzing the antagonistic potential of the lichen microbiome against pathogens by bridging metagenomic with culture studies. Front Microbiol 6:620. doi:10.3389/fmicb.2015.00620

Chagnon P-L (2014) Ecological and evolutionary implications of hyphal anastomosis in arbuscular mycorrhizal fungi. FEMS Microbiol Ecol 88:437-444. doi:10.1111/1574-6941.12321

Cheplick GP, Clay P, Marks S (1989) Interactions between infection by endophytic fungi and nutrient limitation in the grasses Lolium perenne and Fectuca arundinacea. New Phytol 111:89-97. doi:10.1111/j.1469-8137.1989.tb04222.x

Chetan K, Sandhya M, Sarma BK, Singh SP, Singh HB (2014) Unraveling the efficient applications of secondary metabolites of various Trichoderma spp. Appl Microbiol Biotechnol 98:533-544. doi:10.1007/s00253-013-5344-5

Clay K (1987) Effects of fungal endophytes on the seed and seedling biology of Lolium perenne and Festuca arundinacea. Oecologia 73(3):358-362. doi:10.1007/bf00385251

Clay K (1991) Endophytes as antagonists of plant pests. In: Andrews JH, Hirano SS (eds) Microbial Ecology of Leaves. Springer, New York, pp 331-357

Dawkins R (1989) The Extended Phenotype. Oxford University Press, Oxford. ISBN 0-19-288051-9

Druzhinina IS, Seidl-Seiboth V, Herrera-Estrella A, Horwitz BA, Kenerley C, Monte E, Mukherjee PK, Zeilinger S, Grigoriev IV, Kubicek CP (2011) Trichoderma: the genomics of opportunistic success. Nat Rev Microbiol 9:749-759. doi:10.1038/nrmicro2637

Elliott SL, Blanford S, Thomas MB (2002) Host-pathogen interactions in a varying environment: temperature, behavioral fever and fitness. Proc R Soc Lond B 269:1599-1607. doi:10.1098/rspb.2002.2067

Faeth SH, Fagan WF (2002) Fungal endophytes: common host plant symbionts but uncommon mutualists. Integr Comp Biol 42(2): 360-368. doi:10.1093/icb/42.2.360

Farrar JF (1976) The lichen as an ecosystem: observation and experiment. In: Braun DH, Hawksworth DL, Bailey RH (eds) Lichenology: progress and problems. Academic, London, pp 385-406

Fătu A-C, Dinu MM, Ciornei M, Andrei A-M (2015) Biological control of Melolontha melolontha L. larvae with entomopathogenic bioinsecticide based on Beauveria brongniartii. AgroLife Sci J 4(1):64-69

Figueirêdo RECR, Silva JC (2001) Recombination via parasexual cycle in Metarhizium flavoviride. Proc. 21th Congr Bras de Microbiol, Paraná, Brazil 
Fitzpatrick DA (2012) Horizontal gene transfer in fungi. FEMS Microbiol Lett 329(1):1-8. doi:10.1111/j.1574-6968.2011.02465.x

Gibbs JN (1978) Intercontinental epidemiology of Dutch elm diseases. Annu Rev Phytopathol 16:287-307. doi:10.1146/annurev. py.16.090178.001443

Goettel MS (1995) The utility of bioassays in the risk assessment of entomopathogenic fungi. In: Roy et al. (eds) Biotechnology risk assessment: USEPA/USDA, Env. Canada, Agriculture and Agri- Food Canada Proc. Biotechn. Risk Asses. Symposium, Pensacola, Florida, Univ. of Maryland Biotech Inst, College Park, Maryland pp. 2-7

Grodzki W, Kosibowicz M (2015) An attempt to use the fungus Beauveria bassiana (Bals.) Vuill. in forest protection against the bark beetle Ips typographus (L.) in the field. For Res Pap 76(1):517. doi:10.1515/frp-2015-0001

Guo L-D (2010) Molecular diversity and Identification of Endophytic fungi. In: Gherbawy Y, Voigt K (eds) Molecular Identification of Fungi. Springer, Berlin-Heidelberg. doi:10.1007/978-3-642-05042-8

Harman GE, Howell CR, Viterbo A, Chet I, Lorito M (2004) Trichoderma species - opportunistic, avirulent plant symbionts. Nat Rev Microbiol 2:43-56. doi:10.1038/nrmicro797

Hatcher PE (1995) Three-way interactions between plant pathogenic fungi, herbivorous insects and their host plants. Biol Rev 70:639-694. doi:10.1111/j.1469-185x.1995.tb01655.x

Hatcher PE, Paul ND (2001) Plant pathogen-herbivore interactions and their effects on weeds. In: Jeger PJ, Spencer NJ (eds) Biotic interactions in plant-pathogen associations. CABI Wallingford, pp 193-220

Hawksworth DL (1982) Secondary fungi in lichen symbioses: parasites, saprophytes and parasymbionts. J Hattori Bot Lab 52:357-366

Hawksworth DL (2015) Lichenization: The origins of a fungal life-style. In: Upreti DK, Divakar PK, Shukla V, Bajpai R (eds) Recent Advances in Lichenology. Modern methods and approaches in lichen systematics and culture techniques, 2, Springer, New Delhi, pp 1-10. doi:10.1007/978-81-322-2235-4 1

Howell CR (2006) Understanding the mechanisms employed by Trichoderma virens to effect biological control of cotton diseases. Phytopathology 96:178-180. doi:10.1094/PHYTO-96-0178

Husson C, Aguayo J, Revellin C, Frey P, Ioos R, Marçais B (2015) Evidence for homoploid speciation in Phytophthora alni supports taxonomic reclassification in this species complex. Fungal Genet Biol 77:12-21. doi:10.1016/j.fgb.2015.02.013

Jaworski T, Hilszczañski J (2013) The effect of temperature and humidity changes on insect development and their impact on forest ecosystems in the context of expected climate change. For Res Pap 74(4): 345-355. doi:10.2478/frp-2013-0033

Kaur S, Mukerji KG (2006) The Laboulbeniales (Ascomycetes): Distribution and host parasite relationships. In: Mukerji KG, Manoharachary C (eds) Current Concepts in Botany, 3. J.K. International, New Delhi, pp 19-35

Konrad M, Grasse AV, Tragust S, Cremer S (2015) Anti-pathogen protection versus survival costs mediated by an ectosymbiont in an ant host. Proc R Soc Lond B 282(1799):20141976. doi:10.1098/rspb.2014.1976

Kowalski T (1982) Fungi infecting Pinus sylvestris needles of various ages. Eur J For Pathol 12(3):182-190. doi:10.1111/j.1439-0329.1982. tb01392.x

Kowalski T (1993) Fungi in living symptomless needles of Pinus sylvestris with respect to some observed disease processes. J Phytopathol 139(2):129-145. doi:10.1111/j.1439-0434.1993.tb01409.x

Kowalski T (1998) A study on Cenangium shoot dieback of Pinus sylvestris L. in Poland. In: Cech TL et al. (eds) Disease/ Environment Interactions in Forest Decline. Proc. Workshop Working Party Disease/Environment Interactions in Forest Decline, IUFRO 7.02.06. Vienna, Austria, pp 73-81.

Kowalski T, Zych P (2002) Fungi isolated from living symptomless shoots of Pinus nigra growing in different site conditions. Oester Z Pilzk 11:107-116
Kredics L, Antal Z, Dóczi I, Manczinger L, Kevei F, Nagy E (2003) Clinical importance of the genus Trichoderma. Acta Microbiol Immunol Hung 50:105-117. doi:10.1556/amicr.50.2003.2-3.1

Kroon LPNM, Brouwer H, de Cock AWAM, Govers F (2012) The Genus Phytophthora Anno 2012. Phytopathology 102(4):348-364. doi:10.1094/phyto-01-11-0025

Lacroix B, Citovsky V (2016) Transfer of DNA from Bacteria to Eukaryotes. MBio 7(4):e00863-16. doi:10.1128/mBio.00863-16

Lakatos M, Lange-Bertalot H, Büdel B (2004) Diatoms living inside the thallus of the green algal lichen Coenogonium linkii in Neotropical Lowland rain forests. J Phycol 40:7073. doi:10.1046/j.1529-8817.2004.02205.x

Lawrey JD, Diederich P (2003) Lichenicolous fungi: interactions, evolution, and biodiversity. Bryologist 106:81-120

Le Tacon F, Rubini A, Murat C, Riccioni C, Robin C et al (2016) Certainties and uncertainties about the life cycle of the Périgord black truffle (Tuber melanosporum Vittad.). Ann For Sci 73(1): 105-117. doi:10.1007/s13595-015-0461-1, Springer Verlag/EDP Sciences

Lee Sun K, Seung KL, Hanhong B, Sang-Tae S, Jong KL (2014) Effects of water stress on the endophytic fungal communities of Pinus koraiensis needles infected by Cenangium ferruginosum. Mycobiology 42(4):331-338. doi:10.5941/myco.2014.42.4.331

Lumbsch HT, Hipp AL, Divakar PK, Blanco O, Crespo A (2008) Accelerated evolutionary rates in tropical and oceanic parmelioid lichens (Ascomycota). BMC Evol Biol 8:257. doi:10.1186/1471-2148-8-257

Lutzoni F, Pagel M (1997) Accelerated evolution as a consequence of transitions to mutualism. Proc Natl Acad Sci U S A 94(21):1142211427. doi:10.1073/pnas.94.21.11422

Małagocka J, Grell MN, Lange L, Eilenberg J, Jensen AB (2015) Transcriptome of an entomophthoralean fungus (Pandora formicae) shows molecular machinery adjusted for successful host exploitation and transmission. J Invertebr Pathol 128:4756. doi:10.1016/j.jip.2015.05.001

Manion PD (1981) Tree disease concepts. Prentice-Hall, Englewood Cliffs

Mar ais B, Wargo PM (2000) Impact of liming on the abundance and vigor of Armillaria rhizomorphs in Allegheny hardwoods stands. Can J For Res 30:1847-1857

Mayr E (1942) Systematics and the origin of species, from the viewpoint of a zoologist. Harvard University Press, Cambridge

Minchin RF, Ridgway HJ, Condron L, Jones EE (2012) Influence of inoculation with a Trichoderma bioinoculant on ectomycorrhizal colonisation of Pinus radiata seedlings. Ann Appl Biol 161(1): 57-67. doi:10.1111/j.1744-7348.2012.00552.x

Molnár K, Farkas E (2010) Current results on biological activities of lichen secondary metabolites: a review. Z Naturforsch C 65(3-4): 157-173. doi:10.1515/znc-2010-3-401

Nash TH III (1996) Lichen Biology. Cambridge University Press, Cambridge

Newcombe G, Stirling B, McDonald S, Bradshaw HD (2000) Melampsora $\times$ columbiana, a natural hybrid of $M$. medusae and M. occidentalis. Mycol Res 104:261-274. doi:10.1017 /s0953756299001665

Partida-Martinez LP, Hertweck C (2005) Pathogenic fungus harbours endosymbiotic bacteria for toxin production. Nature 437:884-888. doi:10.1038/nature03997

Patil A, Laddha A, Lunge A, Paikrao H, Mahure S (2012) In vitro antagonistic properties of selected Trichoderma species against tomato root rot causing Pythium species. Int J Environ Sci Technol 1(4): $302-315$

Pirttilä AM, Wäli P (2009) Conifer endophytes. In: White J, Torres MS (eds) Defensive Mutualism in Microbial Symbiosis. CRC, Boca Raton, pp 235-246 
Pontecorvo G (1956) The parasexual cycle in fungi. Annu Rev Microbiol 10:393-400. doi:10.1146/annurev.mi.10.100156.002141

Qiu H, Cai G, Luo J, Bhattacharya D, Zhang N (2016) Extensive horizontal gene transfers between plant pathogenic fungi. BMC Biol 14: 41. doi:10.1186/s12915-016-0264-3

Regliński T, Rodenburg N, Taylor JT, Northcott GL, Ah Chee A, Spiers TM, Hill RA (2012) Trichoderma atroviride promotes growth and enhances systemic resistance to Diplodia pinea in radiata pine (Pinus radiata) seedlings. For Pathol 42:75-78. doi:10.1111/j.1439-0329.2010.00710.x

Richards TA, Leonard G, Soanes DM, Talbot NJ (2011) Gene transfer into the fungi. Fungal Biol Rev 25:98-110. doi:10.1016/j.fbr.2011.04.003

Richardson DHS (1999) War in the world of lichens: parasitism and symbiosis as exemplified by lichens and lichenicolous fungi. Mycol Res 103(6):641-650. doi:10.1017/s0953756298008259

Santarius KA (1973) The protective effect of sugars on chloroplast membranes during temperature and water stress and its relationship to frost, desiccation and heat resistance. Planta 113(2):105-114. doi:10.1007/bf00388196

Šatkauskienè I (2012) Microfauna of lichen (Xanthoria parietina) in Lithuania: diversity patterns in polluted and non-polluted sites. Balt For 18(2):255-262

Selbmann L, Grube M, Onofri S, Isola D, Zucconi L (2013) Antarctic epilithic lichens as niches for black meristematic fungi. Biology 2(2):784-797. doi:10.3390/biology2020784

Sierota Z (1976) Influence of acidity on the growth of Trichoderma viride Pers.ex Fr. and on the inhibitory effect of its filtrates against Fomes annosus (Fr.) Cke in artificial cultures. Eur J For Pathol 5:302-311

Sierota Z, Kolk A, Ślusarski S (1998) The causes and course of the phenomenon dieback of shoots Scots pine in north-western Poland in 1995-1997. Prace Instytutu Badawczego Leśnictwa, B 34:75-93

Sobolewski J, Gidelska A, Szczech M, Robak J (2013) Trichoderma spp. as a seed dressing bioproduct against damping-off seedlings of vegetables crops. Prog Plant Prot 53:340-344. doi:10.14199/ppp-2013-093

Speijera D, Lukeš J, Eliášd M (2015) Sex is a ubiquitous, ancient, and inherent attribute of eukaryotic life. Proc Natl Acad Sci U S A 112(29):8827-8834. doi:10.1073/pnas.1501725112

Sterkers Y, Crobu L, Lachaud L, Pages M, Bastien P (2014) Parasexuality and mosaic aneuploidy in Leishmania: alternative genetics. Trends Protistol 30(9):429-435. doi:10.1016/j.pt2014.07.002

Strom NB, Bushley KE (2016) Two genomes are better than one: history, genetics, and biotechnological applications of fungal heterokaryons. Fungal Biol Biotechnol 3:4. doi:10.1186/s40694-016-0022-x

Stukenbrock EH, Bataillon T, Dutheil JY, Hansen TT, Li R, Zala M, McDonald BA, Wang J, Schierup MH (2011) The making of a new pathogen: insights from comparative population genomics of the domesticated wheat pathogen
Mycosphaerella graminicola and its wild sister species. Gen Res 21(12):2157-2166. doi:10.1101/gr.118851.110

Taylor JW, Jacobson DJ, Kroken S, Kasuga T, Geiser DM, Hibbett DS, Fischer MC (2000) Phylogenetic species recognition and species concepts in fungi. Fungal Genet Biol 21: 21-31. doi:10.1006/fgbi.2000.1228

Tekle YI, Anderson R, Lecky AF (2014) Evidence of Parasexual Activity in "Asexual Amoebae" Cochliopodium spp.(Amebozoa): Extensive Cellular and Nuclea Fusion. Protist 165(5):676-687. doi:10.1016/j.protis.2014.07.008

Tranquillini W (1982) Frost-Drought and Its Ecological Significance. In: Lange OL, Nobel PS, Osmond CB, Ziegler H (eds) Physiological Plant Ecology II, Water Relations and Carbon Assimilation, Encyclopedia of Plant Physiology, part 12/B. Springer, Berlin, pp 379-400. doi:10.1007/978-3-642-68150-9 12

Tucci M, Ruocco M, De Masi L, De Palma M, Lorito M (2011) The beneficial effect of Trichoderma spp. on tomato is modulated by the plant genotype. Mol Plant Pathol 12(4):341354. doi:10.1111/j.1364-3703.2010.00674.x

Tunjič M, Korač P (2013) Vertical and horizontal gene transfer in lichens. Period Biol 115(3):321-329

Vilhelmsson O, Sigurbjörnsdóttir A, Grube M, Höfte M (2016) Are lichens potential natural reservoirs for plant pathogens? Mol Plant Pathol 17(2):143-145. doi:10.1111/mpp.12344

Wedin M, Döring H, Gilenstam G (2004) Saprotrophy and lichenization as options for the same fungal species on different substrata: environmental plasticity and fungal lifestyles in the Stictis-Conotrema complex. New Phytol 164:459-465. doi:10.1111/j.1469-8137.2004.01198.x

Weedall GD, Hall N (2015) Sexual reproduction and genetic exchange in parasitic protists. Parasitology 142(Suppl 1):120 127. doi: $10.1017 / \mathrm{S} 0031182014001693$

White A, Begon M, Bowers RG (1996) Host-pathogen system in a spatially patchy environment. Proc R Soc Lond B 263:325-332. doi:10.1098/rspb.1996.0050

Wieloch W, Sacharczuk M, Bogus MI, Jaszczak K (2004) A study for minisatellitic markers of Conidiobolus coronatus pathogenicity to Galleria mellonella larvae. J Invertebr Pathol 85:63-69. doi:10.1016/j.jip.2004.02.005

Wijayawardena BK, Minchella DJ, DeWoody JA (2013) Hosts, parasites, and horizontal gene transfer. Trends Parasitol 29(7):329-338. doi:10.1016/j.pt.2013.05.001

Zedda L, Rambold G (2015) The diversity of lichenized fungi: ecosystem functions and ecosystem services. In: Upreti DK, Divakar PK, Shukla V, Bajpai R (eds) Recent advances in lichenology, vol 2, Modern methods and approaches in lichen systematics and culture technics. Springer, New Delhi, pp 121-145. doi:10.1007/978-81-322-2235-4 7 